\title{
LEMBAGA AMIL ZAKAT NASIONAL (LAZNAS) YAYASAN NURUL HAYAT DALAM MELAKUKAN MANAJEMEN RISIKO REPUTASI
}

\author{
Nisrinah Arofahtus Sholehah \\ Departemen Ekonomi Syariah-Fakultas Ekonomi dan Bisnis-Universitas Airlangga \\ Email: nisnana2724@gmail.com \\ Noven Suprayogi \\ Departemen Ekonomi Syariah-Fakultas Ekonomi dan Bisnis-Universitas Airlangga \\ Email: Noven2005@gmail.com
}

\begin{abstract}
:
The purpose of this study is to find reputational risk management carried out by LAZNAS Nurul Hayat. The use of the method in this research used a qualitative approach through a case study. The main focus in this research is one of the risk that is classified in the International Working Group on Zakat Core Principle (IWGZCP) is reputational risk and the loss of muzakki of four of a kind which is one of the risk that owned by the management of zakat management institutions, besides the distribution of risk, operational risk, and zakat risk transfer among countries. The selection of focus reputation related risk is based on that important for a non-profit organization to having a good reputation of the institution to sustainability. The result of the research indicated that reputation risk management owned by nurul fountain of life begins with the concept of a reputation they believed, namely based on the system and performance. In the implementation, nurul fountain of life chosen to carry preventive measures ( prevention risk management) related to reputation. Seven events are able to exert reputation hayat described related nurul derived from internal and external. Due to belief that the concept of reputation is related to performance and system, so focused prevention is done by the agency to minimize the possibility of internal events which consist of delay in overcoming complaint, late arrivals donations, less working spirit of employees, disobedience to SOP, inadequate accountability and inappropriate beneficiaries of granted aid. The results showed that external factors have no significant effect on the reputation of the institution.
\end{abstract}

Keywords: zakat, risk management, reputation risk, LAZNAS Nurul Hayat Foundation

\section{Pendahuluan}

Zakat merupakan salah satu rukun Islam yang memiliki sifat sosial-ekonomi. Yusuf Qardawi (dalam Hukum Zakat, 1999: 3) disebutkan, bahwasanya zakat merupakan salah satu hal pokok ibadah yang tidak dapat terpisahkan dari shalat. Namun sesungguhnya, zakat adalah satusatunya ibadah yang memiliki dampak terhadap sosial-ekonomi oleh karena itu memiliki pembahasan dalam buku-buku strategi hukum dan ekonomi Islam.

Indonesia sebagai salah satu negara dengan Muslim mayoritas, belum memahami atau bahkan enggan memahami pentingnya zakat ini. Ayat lain yang menunjukkan urgensi dari menunaikan zakat adalah :

Artinya: "Ambillah zakat dari sebagian harta mereka, dengan zakat itu kamu membersihkan dan mensucikan mereka dan berdoalah untuk mereka. Sesungguhnya doa kamu itu (menjadi) ketenteraman jiwa bagi mereka. dan Allah Maha mendengar lagi Maha mengetahui." (Q.S. At-Taubah (9) : 103)

1) Jurnal ini merupakan bagian dari skripsi Nisrinah Arofahtus Sholehah, NIM: 041411431019, yang divji pada tanggal 17 April 2018 
Surat At-Taubah ayat 103 juga turut menjelaskan kewajiban dari zakat yang bersifat memaksa. Di Indonesia kita dihadapakan pada kenyataan bahwa zakat tidak dapat dipaksakan atau bersifat volunteery. Berdasarkan Undangundang No.23 Tahun 201 tentang Pengelolaan Zakat, Bab III Pasal 21 bagian satu tentang Pengumpulan (1) Dalam rangka pengumpulan zakat, muzaki melakukan penghitungan sendiri atas kewajiban zakatnya; (2) Dalam hal tidak dapat menghitung sendiri kewajiban zakatnya, muzaki dapat meminta bantuan BAZNAS. Berdasarkan Undangundang tersebut, dapat dilihat bahwasanya pemerintah belum mewajibkan zakat ini sehingga potensi dari zakat belum sepenuhnya dapat terhimpun dengan optimal. Banyak dari penduduk di Indonesia yang seharusnya sudah memenuhi syarat untuk muzakki, namun belum mengetahui atau bahkan enggan mengeluarkan zakatnya. Pemerintah sebagai pemegang kekuasan tertinggi memiliki peran yang amat penting untuk mendukung perkembangan zakat di Indonesia.

Zakat secara terminologi bahasa berasal dari kata zaka yang berarti berkah, tumbuh, bersih, dan baik. Menurut istilah, zakat berarti sejumlah harta tertentu yang diwajibkan Allah diserahkan kepada orang-orang yang berhak. Jumlah yang dikeluarkan itu disebut zakat karena yang dikeluarkan itu menambah banyak, membuat lebih berarti, dan melindungi kekayaan itu dari kebinasaan (Qardawi, 1999: 34-35). Sebagai salah satu filantropi Islam, zakat memiliki sebuah tujuan utama yakni mentransformasi para mustahiq menjadi muzakki.

Perkembangan zakat juga tidak bisa dilepaskan dari peran amil atau pengelola zakat. Peran amil juga turut berkembang seiring dengan perkembangan zaman, hingga klasifikasi amil tidak hanya berkungkung pada perseorangan namun lembaga. Potensi zakat di Indonesia sendiri tidak dapat disepelekan, sebab jumlah muslim di Indonesia mencapai $85 \%$ dari jumlah penduduk keseluruhan (BPS). Diambil dari Outlook Zakat Indonesia 2017 yang dikeluarkan oleh www.puskasbaznas.com, perkembangan zakat di Indonesia meningkat secara signifikan pada saat UU No. 38/1999 disahkan oleh pemerintah. Berdasarkan UU tersebut, zakat dapat dikelola baik oleh lembaga zakat yang dibentuk pemerintah (Badan Amil Zakat), maupun lembaga zakat yang dibentuk oleh masyarakat (Lembaga Amil Zakat).

Data yang diperoleh dari BAZNAS, jumlah penghimpunan ZIS di Indonesia terus mengalami peningkatan dari tahun ke tahun, hal ini harus menjadi sesuatu yang patut untuk disyukuri dan diapresiasi. Adapun jumlah dari penghimpunan ZIS dari tahun 2002-2015 ini terlampir pada tabel di bawah ini: 
Sholehah, et al/Jurnal Ekonomi Syariah Teori dan Terapan Vol. 6 No. 2 Februari 2019: 198-213; LEMBAGA AMIL ZAKAT NASIONAL (LAZNAS) YAYASAN NURUL HAYAT DALAM MELAKUKAN MANAJEMEN RISIKO REPUTASI

Tabel 1.

Jumlah Penghimpunan ZIS di Indonesia (2002-2016)

\begin{tabular}{|c|c|c|c|c|}
\hline Tahun & $\begin{array}{l}\text { Rupiah } \\
\text { (Miliar) }\end{array}$ & $\begin{array}{l}\text { USD } \\
\text { (juta) }\end{array}$ & $\begin{array}{c}\text { Pertumb } \\
\text { (\%) }\end{array}$ & $\begin{array}{c}\text { Pertumb } \\
\text { GDP }\end{array}$ \\
\hline 2002 & 68.39 & 4.98 & - & 3.70 \\
\hline 2003 & 85.28 & 6.21 & 24.70 & 4.10 \\
\hline 2004 & 150.09 & 10.92 & 76.00 & 5.10 \\
\hline 2005 & 295.52 & 21.51 & 96.90 & 5.70 \\
\hline 2006 & 373.17 & 27.16 & 26.28 & 5.50 \\
\hline 2007 & 740 & 53.86 & 98.30 & 6.30 \\
\hline 2008 & 920 & 66.96 & 24.32 & 6.20 \\
\hline 2009 & 1200 & 87.34 & 30.43 & 4.90 \\
\hline 2010 & 1500 & 109.17 & 25.00 & 6.10 \\
\hline 2011 & 1729 & 125.84 & 15.27 & 6.50 \\
\hline 2012 & 2200 & 160.12 & 27.94 & 6.23 \\
\hline 2013 & 2700 & 196.51 & 19.30 & 5.78 \\
\hline 2014 & 3300 & 240.17 & 25.05 & 5.02 \\
\hline 2015 & 3700 & 269.29 & 10.61 & 5.04 \\
\hline 2016 & 5017 & 365.14 & 37.46 & 5.02 \\
\hline
\end{tabular}

Sumber : Badan Amil Zakat Nasional (2016)

Peningkatan jumlah pengumpulan

ZIS ini sekaligus menjadi alat ukur akan meningkatnya kesadaran masyarakat tentang zakat. Dari tabel tersebut dapat dilihat, bahwasanya semakin tahun selalu mengalami petumbuhan meskipun belum terjadi secara konstan. Peningkatan terbesar terjadi pada tahun 2005, dimana jumlah dana terhimpun dari zakat mencapai 740 miliar rupiah dengan tingkat pertumbuhan mencapai $98,3 \%$. Fluktuasi yang terjadi pada penghimpunan zakat memang terjadi, namun tidak dapat menutup kemungkinan bahwa trend dari zakat ini selalu naik dari tahun ke tahun, hal ini tak lepas dari potensi zakat yang sebenarnya begitu besar hingga mencapai 220 triliun rupiah menurut Gubernur Bank Indonesia, Agus Martowradojo. Lembaga Amil Zakat juga turut mengalami perkembangan yang cukup signifikan dan mengambil peran yang penting dalam dunia perzakatan untuk menghimpun, mengelola, serta mendistribusikan segala bentuk amanah berupa sedekah, infaq, maupun zakat. Fungsi utama adanya LAZ sendiri tetap untuk melakukan pengelolaan zakat, meskipun etap meneriman infaq dan sedekah, namun esensi awal adanya LAZ adalah untuk pengoptimalan potensi zakat. Adapun data mengenai penghimpunan zakat di lembaga dan perseorangan yang diperoleh dari data BAZNAS pada berikut :

Tabel 2.

Penghimpunan ZIS lembaga di Indonesia Tahun 2012-2016

\begin{tabular}{|c|c|c|c|c|c|c|}
\hline Tahun & Perorangan (Rp) & $\begin{array}{l}\text { Porsi } \\
(\%)\end{array}$ & $\begin{array}{l}\text { Lembaga } \\
(\mathrm{Rp})\end{array}$ & \begin{tabular}{|l|} 
Porsi \\
$(\%)$ \\
\end{tabular} & Total & $\begin{array}{l}\text { Jumlah } \\
(\%)\end{array}$ \\
\hline 2012 & 22.186 .801 .085 & $42,3 \%$ & $30.267,494,341$ & $57,7 \%$ & $52,454.295 .426$ & $100,0 \%$ \\
\hline 2013 & 24.955 .456 .166 & $51,8 \%$ & 23.217 .279 .557 & $48,2 \%$ & $48,172.735 .723$ & $100,0 \%$ \\
\hline 2014 & 140.585 .373 .579 & $75,6 \%$ & 45.298 .843 .305 & $24,4 \%$ & 185.884 .216 .884 & $100,0 \%$ \\
\hline 2015 & $269,884.547 .435$ & $78,5 \%$ & $74,089,629,661$ & $21,5 \%$ & 343.974 .177 .096 & $100,0 \%$ \\
\hline 2016 & 366.505 .392 .158 & $79,8 \%$ & $92,666.861 .124$ & $20,2 \%$ & $459,172,253.282$ & $100,0 \%$ \\
\hline \multicolumn{7}{|c|}{ "diambil dari data SIMBA BAZNAS sampai dengan Agustus 201} \\
\hline
\end{tabular}

Sumber: Data BAZNASyang telah diolah

peningkatan. Namun, dapat dilihat pula porsi peningkatan yang terjadi dari tahun ke tahun malah mengalami penurunan. Bahkan penurunan ini terjadi sejak tahun 2013 sebesar 9,2\% jika dibanding dengan tahun 2012, hingga pada tahun 2016 juga semakin menurun prosentasenya mencapai angka $20,2 \%$ saja. Hal ini menjadi sebuah pertanyaan yang membutuhkan penyelesaian, mengingat potensi zakat sebenarnya belum tercapai dengan optimal hingga angka 220 triliun 
Sholehah, et al/Jurnal Ekonomi Syariah Teori dan Terapan Vol. 6 No. 2 Februari 2019: 198-213; LEMBAGA AMIL ZAKAT NASIONAL (LAZNAS) YAYASAN NURUL HAYAT DALAM MELAKUKAN MANAJEMEN RISIKO REPUTASI

rupiah. Untuk itu, dibawah ini terdapat data mengenai jumlah muzakki atau wajib zakat yang terdata oleh BAZNAS untuk memudahkan dalam membandingkan adakah keselarasan terkait peningkatan jumlah dana terhimpun dengan jumlah wajib zakat yang ada pada tabel berikut ini:

Tabel 3.

Total Muzakki di Indonesia (2012-2016)

\begin{tabular}{|c|r|r|r|r|r|c|}
\hline Tahun & $\begin{array}{c}\text { Perorangan } \\
\text { (jiwa) }\end{array}$ & $\begin{array}{c}\text { Porsi } \\
(\%)\end{array}$ & $\begin{array}{c}\text { Lembaga } \\
\text { (jiwa) }\end{array}$ & $\begin{array}{c}\text { Porsi } \\
(\%)\end{array}$ & Total & $\begin{array}{c}\text { Jumlah } \\
(\%)\end{array}$ \\
\hline 2012 & 700 & $57,4 \%$ & 520 & $42,6 \%$ & 1.220 & $100,0 \%$ \\
\hline 2013 & 33.492 & $90,8 \%$ & 3.396 & $9,2 \%$ & 36.888 & $100,0 \%$ \\
\hline 2014 & 28.033 & $92,9 \%$ & 2.143 & $7,1 \%$ & 30.176 & $100,0 \%$ \\
\hline 2015 & 56.873 & $94,9 \%$ & 3.066 & $5,1 \%$ & 59.939 & $100,0 \%$ \\
\hline 2016 & 119.332 & $94,0 \%$ & \multicolumn{7}{|c|}{7.568} & $6,0 \%$ & 126.900 & $100,0 \%$ \\
\hline \multicolumn{7}{|c|}{ "diambil dari data SIMBA BAZNAS sampai dengan Agustus 2016} \\
\hline
\end{tabular}

Sumber : Data BAZNAS yang telah diolah

$$
\text { Ternyata, kedua tabel }
$$

menunjukkan hal yang serupa, yakni proporsi yang ada mengalami kenaikan ini didominasi oleh penghimpunan dana dari perorangan bukan lembaga. Padahal, adanya lembaga amil diharapkan mampu melakukan tugas dan fungsinya sebagaimana tertulis pada UU No. 23/2011 Pasal 3 yang berbunyi, "meningkatkan efektivitas dan efisiensi pelayanan dalam pengelolaan zakat, dan meningkatkan manfaat zakat untuk mewujudkan kesejahteraan masyarakat dan penanggulangan kemiskinan." Data diatas juga menunjukkan bahwa lembaga amil zakat belum mampu menjalankan fungsinya sebagaimana mestinya. Tabel tersebut juga menunjukkan trend yang semakin menurun dari penghimpunan yang dilakukan oleh lembaga, padahal kondisi ideal yang terjadi adalah meningkatnya kepercayaan masayarakat terhadap lembaga amil sehingga optimalisasi dari potensi zakat ini dapat tercapai.

Salah satu faktor utama penyebab belum optimalnya pemanfaatan instrumen zakat dalam pembangunan nasional adalah masih lemahnya tata kelola perzakatan yang berujung pada belum optimalnya sistem pengelolaan zakat nasional. Tidak hanya itu, persoalan tata kelola ini juga dihadapi pada tingkat global.Sehingga sejak Agustus 2014 muncul gagasan untuk memformulasikan suatu dokumen yang dapat menjadi referensi pengelolaan zakat internasional dengn tujuan agar instrumen zakat ini dapat ditingkatkan pengelolaannya. Gagasan ini kemudian diimplementasikan dalam bentuk kegiatan International Working Group on Zakat Core Principles (IWGZCP) yang diinisiasi oleh BAZNAS, Bank Indonesia, dan Islamic Development Bank (IDB). Hingga saat ini, kegiatan IWGZCP telah dilaksanakan sebanyak empat kali, dan telah menghasilkan draft dokumen yang terdiri dari 6 dimensi dan 18 prinsip utama pengelolaan zakat dunia. Keenam dimensi tersebut adalah dasar hukum pengelolaan zakat, supervisi zakat, tata kelola zakat, fungsi intermediasi, manajemen resik, dan kepatuhan syariah (Baek, 2016). Selain empat macam manajemen pengelolaan zakat di atas, berdasarkan pertemuan perdana International Working Group on Zakat Core Principles (IWGZCP) disepakati bahwa identifikasi resiko dalam 
pengelolaan zakat merupakan hal yang sangat penting karena akan mempengaruhi kualitas pengelolaan zakat ke depan.

Setidaknya, ada empat jenis resiko yang telah teridentifikasi dan dunia perzakatan harus memiliki konsep yang jelas dalam memitigasi resiko-resiko tersebut, yakni :

1. Resiko reputasi dan kehilangan muzakki

2. Risiko penyaluran

3. Risiko operasional

4. Risiko transfer zakat antar negara

Reputasi yang buruk akan menyebabkan hilangnya muzakki dan berkurangnya kepercayaan masyarakat terhadap lembaga amil. Sebuah reputasi juga akan menentukan masa depan dari lembaga amil, untuk itu penting adanya melakukan manajemen risiko reputasi yang tepat agar kepercayaan dan nilai dari perusahaan dapat diterima dengan baik oleh para muzakki, mustahiq, maupun pemerintah.

Pentingnya manajemen risiko reputasi ini juga turut mempengaruhi kepercayaan pemerintah. Pada tahun 2015 Ialu, Bu Tri Rismaharini selaku walikota Surabaya membekukan dana BAZ karena hilangnya kepercayaan terhadap pengelolaan dari dana ummat ini dikarenakan adanya dugaan penyelewengan dana lebih dari 50 persen yang diketahui dari laporan pertanggungajwaban yag diberikan oleh BAZ Surabaya. Dikutip dari republika.co.id
(27 Januari 2015) langkah yang diambil oleh bu Risma ini tepat karena sebuah lembaga filantropi harus akuntabel dan transparan. Jika lembaga filantropi bisa meningkatkan hal itu maka kepercayaan masyarakat juga akan meningkat. Kasus ini layak menjadi bahan evaluasi bagi OPZ lain secara umum, baik bentukan pemerintah maupun swasta. Beberapa hal tersebut dapat menunjukkan urgensi dari manajemen risiko yang harus dilakukan oleh organisasi-organisasi pengelola zakat, baik bentukan pemerintah (BAZ) maupun bentukan swasta (LAZ) agar hal serupa tidak terjadi lagi di kemudian hari.

Nurul Hayat, adalah sebuah yayasan yang berdiri pada tahun 2001 dan berhasil menjadi LAZNAS pada tahun 2015 sesuai dengan SK Meteri Agama RI no 422 tahun 2015 hal ini turut serta membuktikan bahwasanya Nurul Hayat mampu menjadi lembaga amil yang dipercaya masyarakat, bahwa memperoleh predikat LAZNAS dari BAZNAS sebuah lembaga amil harus menghimpun dana zakat sebesar 50 miliar rupiah dan Nurul Hayat mampu mencapainya dalam kurun waktu yang relatif singkat yakni sekitar 14 tahun. Nurul Hayat juga menjadi satu-satunya lembaga amil yang gaji karyawannya tidak bergantung pada penghimpunan dana muzakki dengan memiliki cita-cita menjadi lembaga yang mandiri, semua gaji karyawan dibiayai oleh dana hasil usaha yayasan sehingga $100 \%$ ZIS yang terhimpun disalurkan untuk program-program sosial dan dakwah. 
Pada tahun 2017 tepatnya pada tanggal 25 Agustus kemarin, Nurul Hayat juga memperoleh predikat "Pertumbuhan Pengumpulan ZIS Terbaik" dari BAZNAS pada acara BAZNAS Award. Sebuah prestasi ini mampu memberikan gambaran bagaimana manajemen risiko yang dilakukan oleh Nurul Hayat, terutama dalam mengatasi risiko reputasi dan kehilangan muzakki. Untuk itulah, penulis ingin menggali lebih dalam bagaimana yayasan ini melakukan manajemen risiko reputasinya.

\section{Rumusan Masalah}

Berdasarkan latar belakang tersebut, rumusan masalah yang akan diangkat apada penelitian kali ini adalah: "Bagaimana manajemen risiko reputasi yang dilakukan oleh Lembaga Amil Zakat Nasional (LAZNAS) Yayasan Nurul Hayat?"

\section{Tujuan Penelitian}

Tujuan dari penelelitian ini adalah : Untuk mengetahui manajemen risiko reputasi yang dilakukan oleh Lembaga Amil Zakat Nasional (LAZNAS) Nurul Hayat.

\section{LANDASAN TEORI}

Prinsip Islam tentang halal-haram (Qardawi, 2007:17) menyebutkan

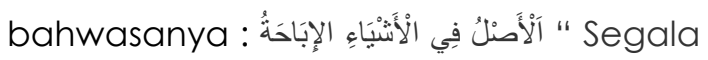
sesuatu pada asalnya mubah". Dalam konteks yang lebih rinci, hukum segala muamalah adalah boleh sampai dengan adanya sesuatu yang mengharamkannya. Sehingga, manajemen risiko dalam Islam akan memperhatikan ruhaniah halal dan haram yang merupakan landasan utama dalam setiap perencanaan, pelaksanaan dan semua kegiatan yang dilakukan untuk mencapai segala sesuatu. Salah satu bukti manajemen risiko memang diperbolehkan dalam Islam ini adalah kisah Nabi Yusuf yang difirmankan Allah dalam :

Artinya : Yusuf berkata: "Supaya kamu bertanam tujuh tahun (lamanya) sebagaimana biasa; Maka apa yang kamu tuai hendaklah kamu biarkan dibulirnya kecuali sedikit untuk kamu makan.(Q.S. Yusuf (12) : 47)

Allah juga telah memerintahkan kita sebagai seorang umat beriman untuk senantiasa melakukan dan mengusahakan seoptimal mungkin segala sesuatu meskipun kita tidak mengetahui hasilnya namun ikhtiar terbaik harus kita lakukan. Hal ini tertuang dalam firman-Nya

Artinya : Hai orang-orang yang beriman, bertakwalah kepada Allah dan hendaklah Setiap diri memperhatikan apa yang telah diperbuatnya untuk hari esok (akhirat); dan bertakwalah kepada Allah, Sesungguhnya Allah Maha mengetahui apa yang kamu kerjakan. (Q.S. Al-Hasyr (59) : 18)

Dari dua ayat diatas, dapat dilihat bahwasanya melakukan manajemen risiko merupakan salah satu ikhtiar yang dapat dilakukan oleh seorang muslim dalam melaksanakan muamalah, tentunya tanpa menyalahi hal-hal yang ditentang oleh syariat dan sesuai dengan koridor-koridor yag ada.

$$
\text { Menurut International Working }
$$

Group on Zakat Core Principles (IWGZCP) 
bahwa identifikasi resiko dalam pengelolaan zakat merupakan hal yang sangat penting karena akan mempengaruhi kualitas pengelolaan zakat. Ada empat jenis resiko dalam pengelolaan zakat, yaitu:

1. Resiko Reputasi dan Kehilangan Muzakki.

Reputasi merupakan faktor yang sangat penting karena akan menentukan loyalitas muzakki dan tingkat kepercayaan publik dalam membayarkan kewajiban zakatnya. Oleh karena itu, segala hal yang dapat menimbulkan dampak pada buruknya reputasi kelembagaan amil harus dapat diminimalisir. Sebagai contoh, manajemen penyaluran yang bersifat asal-asalan, apalagi dengan cara mengumpulkan mustahik untuk berbaris di lapangan mengantri pembagian vang, hal ini merupakan tindakan yang dapat menurunkan kredibilitas institusi amil sehingga berpotensi merusak reputasi lembaga. Inilah esensi mengapa resiko reputasi dan kehilangan muzakki ini harus dikelola dengan baik. Institusi zakat juga harus memiliki prosedur mitigasi resiko jika terjadi hal-hal yang tidak diinginkan.

2. Resiko penyaluran

$$
\text { Hal-hal yang berkaitan }
$$
dengan Resiko Penyaluran adalah terkait dengan ketidaksesuaian antara rencana kerja penyaluran dengan realisasi di lapangan dikarenakan beragam faktor, baik yang bersifat internal dan eksternal kelembagaan, yang disengaja dan tidak disengaja, serta dalam keadaan terpaksa (force majeur). Misalnya, pada program tahun ini telah direncanakan bahwa alokasi dana zakat untuk bantuan korban bencana alam adalah sebesar $20 \%$ dari total dana yang akan disalurkan. Ternyata muncul bencana yang tidak terprediksikan sebelumnya, sehingga angka $20 \%$ menjadi tidak cukup. Dimisalkan yang diperlukan adalah $30 \%$. Kekurangan 10\%, jika tidak mampu diatasi dengan penghimpunan dana yang baru, maka harus diatasi dengan mengambil alokasi dana untuk program lain. Jika ini yang terjadi, maka akan menimbulkan masalah dengan mustahik program lain. Bagaimana memitigasi resiko ini, maka lembaga amil harus memiliki prosedur (SOP) antisipasi yang tepat dan efektif.

3. Resiko Operasional

$$
\text { Hal-hal yang berkaitan }
$$
dengan Resiko Operasional adalah kegiatan operasional kelembagaan amil. Misalnya, hilangnya sejumlah database karena belum baiknya administrasi pengarsipan dan penyimpanan file yang dimiliki institusi amil. Atau 
keterlambatan penyaluran dana zakat untuk program pemberdayaan mustahik karena prosedur yang berubah-ubah, maka hal ini berpotensi mengganggu kelancaran program lembaga secara keseluruhan. Karena itu, memiliki sistem pengadministrasian yang tepat dan prosedur penyaluran yang tepat dan tidak mudah berubah merupakan bagian dari upaya meminimalisir resiko operasional.

4. Resiko transfer zakat antarnegara Resiko yang dapat muncul antara lain apakah dana zakat yang diberikan oleh negara donor kepada negara penerima telah sesuai dengan perencanaan yang disepakati atau tidak. Perlu ada alat ukur sebagai kontrol untuk meminimalisir terjadinya penyalahgunaan dana zakat.

Selain manajemen pengelolaan zakat, prinsip akuntabilitas dan transparansi keuangan merupakan hal-hal yang harus diperhatikan dalam pengelolaan zakat. Tujuan pelaksanaan prinsip akuntabilitas dan transparansi kevangan adalah sejalan dengan tujuan pengelolaan zakat dalam UU No. 23 Tahun 2011, yaitu meningkatnya efektivitas dan efisiensi pelayanan dalam pengelolaan zakat, dan meningkatny manfaat zakat untuk mewujudkan kesejahteraan masyarakat dan penanggulangan kemiskinan.
Dalam rangka meminimalisasi risiko yang dapat menimbulkan kerugian, maka suatu organisasi harus menerapkan manajemen resiko (Arifin, 2009: 272). Salah satu hal yang harus dilakukan adalah melakukan penilaian risiko. Penilaian risiko adalah sebuah kegiatan penialian atas kemungkinan kejadian yang mengancam pencapaian tujuan dan sasaran. Penilaian risiko dibutuhkan untuk dapat mengendalikan kemungkinankemungkinan buruk yang dapat terjadi).

Penilaian risiko reputasi pada penelitian ini menggunakan model ISO 9001:2015 yang dimodifikasi oleh penulis dengan memfokuskan bagian risiko reputasi dan penyebabnya sehingga nilai yang dikeluarkan adalah hasil dari interpretasi yang dilakukan Nurul Hayat dalam melakukan manajemen risiko reputasinya. Penilaian risiko ISO dibentuk berdasarkan frekuensi kejadian yang mungkin (likelihood) dan pengaruh yang mungkin terjadi (impact).

Standar penilaian ISO dapat digambarkan dalam peta sebagai berikut :

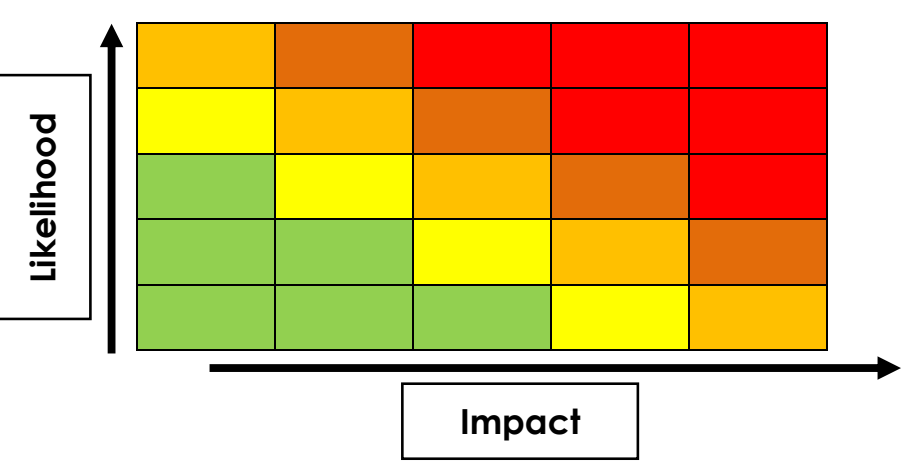

Gambar 1. Peta Risiko ISO 9001:2015 
Sholehah, et al/Jurnal Ekonomi Syariah Teori dan Terapan Vol. 6 No. 2 Februari 2019: 198-213; LEMBAGA AMIL ZAKAT NASIONAL (LAZNAS) YAYASAN NURUL HAYAT DALAM MELAKUKAN MANAJEMEN RISIKO REPUTASI

Peta risiko tersebut akan dihasilkan jika kita melakukan penghitungan risiko dengan cara mengalikan potensi kejadian (likelihood) dengan besarnya dampak yang mungkin terjadi (impact), untuk mempermudah melakukan pengklasifikasian dari ragam risiko diatas dapat dilihat pada tabel di bawah ini :

Tabel 4.

Klasifikasi Penilaian Risiko ISO 9001:2015

\begin{tabular}{|l|l|}
\hline \multicolumn{2}{|c|}{ Level of Risk } \\
Minimum- & \multicolumn{1}{|c|}{ Keterangan } \\
\hline $1-5$ & Sangat rendah (SR) \\
\hline $6-10$ & Rendah (R) \\
\hline $11-15$ & Sedang (S) \\
\hline $16-20$ & Tinggi (T) \\
\hline $21-25$ & Sangat tinggi (ST) \\
\hline
\end{tabular}

Sumber : Badan POM RI (2017)

$$
\text { Masing-masing frekuensi }
$$

(likelihood) dan pengaruh (impact) memiliki batas nilai 1 untuk skala yang terendah dan 5 untuk skala yang tertinggi dengan rincian sebagai berikut :

Tabel 5.

Pemberian Nilai Daftar Risiko

\begin{tabular}{|c|c|c|c|}
\hline \multirow{2}{*}{$\begin{array}{c}\text { Nila } \\
\text { i }\end{array}$} & \multirow[t]{2}{*}{ Kriteria } & \multicolumn{2}{|c|}{ Keterangan } \\
\hline & & Likelihood & Impact \\
\hline 1 & $\begin{array}{l}\text { Sangat } \\
\text { rendah } \\
\text { (rare) }\end{array}$ & $\begin{array}{l}\text { Hampir tidak } \\
\text { pernah terjadi, } \\
\text { terjadi } 1 \text { kali dalam } \\
\text { setahun }\end{array}$ & $\begin{array}{l}\text { Tidak berdampak } \\
\text { negatif pada } \\
\text { reputasi unit kerja }\end{array}$ \\
\hline 2 & $\begin{array}{l}\text { Rendah } \\
\text { (unlikely) }\end{array}$ & $\begin{array}{l}\text { Mungkin terjadi, } \\
\text { terjadi } 2-3 \quad \text { kali } \\
\text { dalam setahun }\end{array}$ & $\begin{array}{l}\text { Berdampak negatif } \\
\text { pada reputasi }\end{array}$ \\
\hline 3 & $\begin{array}{l}\text { Sedang } \\
\text { (moderate } \\
\text { ) }\end{array}$ & $\begin{array}{l}\text { Jarang terjadi, } \\
\text { terjadi } 4-6 \quad \text { kali } \\
\text { dalam setahun }\end{array}$ & $\begin{array}{l}\text { Berdampak negatif } \\
\text { pada reputasi } \\
\text { kepala unit } \\
\text { kerja/satuan kerja }\end{array}$ \\
\hline 4 & $\begin{array}{l}\text { Tinggi } \\
\text { (likely) }\end{array}$ & $\begin{array}{l}\text { Sering terjadi, } \\
\text { terjadi } 7-11 \quad \text { kali } \\
\text { dalam setahun }\end{array}$ & $\begin{array}{l}\text { Berdampak negatif } \\
\text { pada kepala } \\
\text { yayasan }\end{array}$ \\
\hline 5 & $\begin{array}{l}\text { Sangat } \\
\text { tinggi }\end{array}$ & $\begin{array}{l}\text { Hampir pasti } \\
\text { terjadi, tejadi lebih }\end{array}$ & $\begin{array}{l}\text { Berdampak negatif } \\
\text { pada reputasi }\end{array}$ \\
\hline
\end{tabular}

\begin{tabular}{|l|l|l|lr|}
\hline $\begin{array}{l}\text { (almost } \\
\text { certain) }\end{array}$ & $\begin{array}{l}\text { dari } 11 \text { kali dalam } \\
\text { setahun }\end{array}$ & $\begin{array}{l}\text { kepala } \\
\text { dan }\end{array}$ & $\begin{array}{r}\text { yayasan } \\
\text { eksternal } \\
\text { dalam }\end{array}$ & skala \\
& nasional & \\
\hline
\end{tabular}

\section{METODE PENELITIAN}

Pendekatan penelitian yang digunakan dalam skripsi ini dalah pendekatan kualitatif. Bungin (2007) mengutip dari pernyataan Yin (2002) menjelaskan bahwa pendekatan kualitatif adalah sebah pendekatan yang menggunakan data berupa kaliat tertulis atau lisan, peristiwa-peristiwa, pengetahuan atau proyek yang bersifat deskriptif.

Analisis data bertujuan untuk menyusus data dalam cara yang bermakna sehingga mudah dan dapat dipahami. Patton (1990) menyatakan bahwa tidak ada cara paling benar secara absolut untuk mengorganisasi, meganalisis, dan menginterpertasikan data kualitatif. Oleh karenanya, prosedur analisis data dalam penelitian kali ini memiliki beberapa tahapan diantarnya :
a. Data reduction
b. Data display
c. Conclusion Verification Drawing

\section{HASIL DAN PEMBAHASAN}

\section{Hasil Identifikasi Risiko}

Berdasarkan hasil penelitian, penilaian terkait risiko reputasi dari nurul hayat dilakukan oleh Manajer ZIS adalah sebagi berikut :

Tabel 6.

Risiko Reputasi Nurul Hayat

\begin{tabular}{|c|c|c|c|c|c|}
\hline No & $\begin{array}{c}\text { Risk Event (uraian } \\
\text { peristiwa risiko) }\end{array}$ & Sumber & \multicolumn{3}{|c|}{ Score } \\
\cline { 4 - 6 } & & & Frek. & $\begin{array}{c}\text { Dam } \\
\text { pak }\end{array}$ & Level of risk \\
\hline
\end{tabular}




\begin{tabular}{|c|c|c|c|c|c|}
\hline 1. & $\begin{array}{l}\text { Keterlambatan } \\
\text { mengatasi } \\
\text { komplain }\end{array}$ & Internal & 2 & 3 & $6(R)$ \\
\hline 2. & $\begin{array}{l}\text { Keterlambatan } \\
\text { penjemputan } \\
\text { donasi }\end{array}$ & Internal & 2 & 3 & $6(R)$ \\
\hline 3. & $\begin{array}{lr}\text { Tidak } & \text { adanya } \\
\text { semangat } & \text { kerja } \\
\text { karyawan } & \end{array}$ & Internal & 1 & 4 & $4(\mathrm{R})$ \\
\hline 4. & $\begin{array}{l}\text { Tidak dipatuhinya } \\
\text { sOP yang ada }\end{array}$ & Internal & 1 & 3 & 3 (SR) \\
\hline 5. & $\begin{array}{l}\text { Akuntabilitas yang } \\
\text { kurang baik }\end{array}$ & Internal & 1 & 4 & $4(R)$ \\
\hline 6. & $\begin{array}{l}\text { Tidak tepat sasaran } \\
\text { bantuan yang } \\
\text { diberikan }\end{array}$ & Internal & 1 & 3 & 3 (SR) \\
\hline 7. & $\begin{array}{l}\text { Persaingan tidak } \\
\text { sehat antar LAZ }\end{array}$ & Eksternal & 1 & 2 & 2 (SR) \\
\hline
\end{tabular}

Sumber : Hasil pengisian tabel risiko oleh narasumber manajer ZIS (2018)

Hasil akhir dari penilaian risiko tersebut jika digambarkan dalam matriks penilaian risiko, akan menghasilkan data sebagai berikut :

Tabel 7.

Matriks Penilaian Risiko Reputasi

\begin{tabular}{|l|c|c|c|c|c|}
\hline \multirow{2}{*}{$\begin{array}{l}\text { Peluang/ } \\
\text { Frekuensi }\end{array}$} & \multicolumn{5}{|c|}{ Akibat/Dampak } \\
\cline { 2 - 6 } & $\begin{array}{c}\text { (1) } \\
\text { Sangat } \\
\text { Renda }\end{array}$ & $\begin{array}{c}\text { (2) } \\
\text { Rendah }\end{array}$ & $\begin{array}{c}\text { (3) } \\
\text { Sedang }\end{array}$ & $\begin{array}{c}\text { (4) } \\
\text { Tinggi }\end{array}$ & $\begin{array}{c}\text { (5) } \\
\text { Sangat } \\
\text { Tinggi }\end{array}$ \\
\hline $\begin{array}{l}\text { (5) } \\
\text { Sangat } \\
\text { tinggi }\end{array}$ & & & & & \\
\hline $\begin{array}{l}\text { (4) Tinggi } \\
\text { (3) }\end{array}$ & & & & & \\
Sedang & & & 1,2 & & \\
\hline $\begin{array}{l}\text { (2) } \\
\text { Rendah }\end{array}$ & & & 4,6 & 3,5 & \\
\hline $\begin{array}{l}\text { (1) } \\
\text { Sangat } \\
\text { rendah }\end{array}$ & & & & & \\
\hline
\end{tabular}

Sumber: Olah data peneliti

Berdasarkan hasil analisis penelitian tersebut, dapat ditarik beberapa pokok pembahasan dalam penelitian yang dilakukan, diantaranya:

1. Konsep Reputasi bagi LAZNAS Nurul Hayat adalah output dari kinerja dan sistem yang sudah terbentuk. Sehingga, untuk mendapatkan reputasi yang baik, maka Nurul Hayat menciptakan sistem dan kinerja yang optimal dan profesional.

2. Hasil identifikasi risiko reputasi LAZNAS Nurul Hayat terbagi menjadi dua berdasarkan sumbernya, yakni risiko yang berasal dari sumber internal (keterlambatan mengatasi komplain, keterlambatan penjemputan donasi, tidak adanya semangat kerja karawan, tidak dipatuhinya SOP yang ada, hilangnya kepercayaan donatur, akuntabilitas yang kurang baik, serta tidak tepat sasaran bantuan yang diberikan) dan risiko yang berasal dari sumber eksternal (persaingan tidak sehat antar LAZ).

3. Hasil penilaian risiko reputasi LAZNAS Nurul Hayat menunjukkan bahwa risiko-risiko reputasi yang ada memiliki nilai rendah dan sangat rendah. Lima dari delapan diantaranya adalah rendah, yang terdiri atas keterlamabtan mengatasi komplain (6), keterlambatan penjemputan donasi (6), tidak adanya semangat kerja karyawan (4), serta akuntabilitas yang kurang baik (6). Sedangkan, tidak dipatuhinya SOP (3), tidak tepat sasaran bantuan yang diberikan (3), dan persaingan tidak sehat antar LAZ (2) merupakan risiko sangat rendah. 
4. Penanganan risiko reputasi LAZNAS Nurul Hayat berfokus dengan cara mencari akar permasalahan dari masing-masing risiko kemungkinan peristiwa untuk digali dan diselesaikan sebelum peristiwa itu benar-benar terjadi (tindakan preventif).

Reputasi merupakan output atau bonus yang diperoleh oleh suatu lembaga setelah melakukan tata kelola sistem dan kinerja, hal inilah yang menjadi dasar dari konsep reputasi yang dipercaya oleh Nurul Hayat. Nurul Hayat sendiri memilki SOP yang cukup baik guna menjaga reputasi lembaga. Selain itu, SDM yang ada juga memiliki kinerja yang baik karena selalu dilakukan pembinaan rutinan terhadap para karyawan yang ada.

Konsep yang diangkat oleh Nurul Hayat ini selaras dengan konsep reputasi yang dikemukakan oleh Basya dan Sati bahwa reputasi juga baru bertahan dan sustainable apabila konsistennya perkataan dan perbuatan (2006: 6). Dalam Islam sendiri, tidak terdapat konsep reputasi ini, namun jika mau menghubungkan terkait konsep kesamaan antar perkataan dan perbuatan ini, dapat diambil sebuah konsep tentang amanah. Dalam Q.S. AlBaqarah ayat 283 Allah berfirman:

Artinya:"...Jika sebagian kamu mempercayai sebagian yang lain, Maka hendaklah yang dipercayai itu menunaikan amanatnya (hutangnya) dan hendaklah ia bertakwa kepada Allah Tuhannya;..."(Q.S Al-Baqarah (2) : 283)
Potongan surat tersebut sekaligus menegaskan pentingnya menjaga amanah. Dan, hubungan denga reputasi ini terbentuk ketika masyarakat sudah menilai reputasi Nurul Hayat baik dan akhirnya mempercayakan dana mereka untuk disalurkan melalui lembaga ini, maka wajib bagi mereka untuk melaksanakan amanah ini.

Salah satu hal yang menjadi ciri utama dan menjadi unggulan bagi LAZNAS Nurul Hayat adalah kemandirian yang menjadi komitmen mereka. Hal tersebutlah, dapat kita temui pada portal website mereka di www.nurulhayat.org yang juga menjadi headline terbesar yang dipampang disana, yang sekaligus membedakan Nurul Hayat dengan LAZLAZ yang lain dan secara tidak langsung dapat memberikan dampat yang baik terhadap reputasi yang mereka miliki. Kemandirian ini dilatarbelakangi oleh aktivitas usaha dari yayasan yang mampu menopang gaji karyawannya. Sehingga, struktur dari LAZNAS Nurul Hayat tidak dapat disamakan dengan LAZNAS pada umumnya, karena LAZ sendiri merupakan salah satu lingkup kecil dari keseluruhan yayasan.

Reputasi yang dibentuk Nurul Hayat juga mampu memberikan dampak pada penghimpunan yang mereka lakukan. Hal tersebut dapat dilihat pada tabel 4.3 yang menunjukkan tingkat kepercayaan masyarakat juga meningkat kepada Nurul Hayat. Hal ini juga menunjukkan Nurul Hayat mampu 
mengoptimalkan tugas dari lembaga amil yang tertera pada UU No.23 tahun 2011.

Berdasarkan teori identifikasi risiko yang dikemukakan oleh Bahar dan Crandall (1990) disebutkan bahwa proses dalam manajemen risiko meliputi tahapan identifikasi yang terdiri dari: membuat daftar kejadian yang menyebabkan kerugian, membuat checklist kerugian potensial, serta memuat klasifikasi atas kerugain. Proses tersebut juga dilaksanakan dalam LAZNAS Nurul Hayat.

Berdasarkan hasil penelitian,

LAZNAS Nurul Hayat terdapat delapan peristiwa yang dapat mempengaruhi reputasi dari Nurul Hayat. Tujuh diantaranya berasal dari sumber internal, dan satu serta merupakan dari sumber eksternal. Kelima risiko internal ini diantaranya adalah: keterlambatan mengatasi komplain, keterlambatan penjemputan donasi, tidak adanya semangat kerja karawan, tidak dipatuhinya SOP yang ada, hilangnya kepercayaan donatur, akuntabilitas yang kurang baik, serta tidak tepat sasaran bantuan yang diberikan). Sedangkan, untuk risiko yang berasal dari eksternal adalah persaingan tidak sehat antar LAZ. Dari hasil identifikasi dapat ditarik sebuah kesimpulan, bahwa risiko Nurul Hayat ini dipengaruhi oleh sistem dan kinerja (internal) yang mereka jadikan sebagai konsep reputasi. Sedangkan faktor eksternal, dinilai tidak akan memberikan dampak besar yang cukup signifikan.

Penilaian risiko adalah sebuah kegiatan penialian atas kemungkinan kejadian yang mengancam pencapaian tujuan dan sasaran. Penilaian risiko dibutuhkan untuk dapat mengendalikan kemungkinan-kemungkinan buruk yang dapat terjadi (Arifin, 2009: 272).

Berdasarkan identifikasi risiko reputasi LAZNAS Nurul Hayat, diperoleh hasil bahwa lima dari delapan peristiwa yang dianggap mampu mempengaruhi reputasi memiliki tingkat yang rendah, sedangkan tiga sisanya memiliki nilai yang sangat rendah. Hasil ini tentu tidak terbentuk serta merta.

Selanjutnya, diklasifikasikanlah setiap kejadian berdasarkan score akhir yang ditemukan untuk nantinya dapat diambil kesimpulan terkait risiko mana yang harus diprioritaskan. Sedangkan, untuk memperoleh score akhir sendiri harus dilakukan analisis terkait dampak dan frekuensi kejadian. Hal itu dilakukan, agar dalam melakukan identifikasi risiko reputasi tidak ada hal yang terlewat dan menyebabkan kerugian yang besar. Untuk frekuensi terbesar berada di risiko keterlambatan mengatasi komplain dan keterlambatan penjemputan dengan nilai 2. Sedangkan, untuk nilai dampak terbesar berada di risiko tidak adanya semangat kerja, hilangnya kepercayaan donatur, serta akuntabilitas yang kurang baik. Secara ringkas, risiko-risiko reputasi yang dimiliki oleh Nurul Hayat berada paa skala 2 sampai dengan 6 dengan klasifikasi sangat rendah dan rendah. Al Bahar dan Crandall (1990) menyebutkan bahwa ada empat strategi alternatif yang dapat dilakukan dalam melakukan 
penanganan risiko yang terdiri dari menghindari risiko, mencegah risiko dan mengurangi kerugian, meretensi risiko, serta mentransfer risiko.

Penanganan risiko yang dilakukan oleh Nurul Hayat memilih untuk melakukan upaya mitigasi yang terdiri dari menghindari risiko serta mencegah risiko dan mengurangi kerugian dengan cara mengatasi akar dari masing-masing risiko. Penanganan dilakukan dengan mencari tau penyebab-penyebab dari masingmasing risiko dan melakukan penyelasaian dari beberapa aspek dan sudut pandang. Banyaknya sudut pandang yang digunakan, adalah sebagai salah satu upaya menghilangkan kemungkinan-kemungkinan lain yang akan timbul, sehingga permasalahan bisa benar-benar terselesaikan.

Dalam Islam sendiri, upaya melakukan pencegahan ini tercermin dalam surat:

Artinya: " Hai orang-orang yang beriman, bertakwalah kepada Allah dan hendaklah Setiap diri memperhatikan apa yang telah diperbuatnya untuk hari esok (akhirat); dan bertakwalah kepada Allah, Sesungguhnya Allah Maha mengetahui apa yang kamu kerjakan." (Q.S. Al-Hasyr (59) :18)

Selain itu, upaya melakukan tabayyun atau pencarian informasi dari banyak sumber juga dituntunkan dalam firman-Nya :
Artinya: "Hai orang-orang yang beriman, jauhilah kebanyakan purba-sangka (kecurigaan), karena sebagian dari purbasangka itu dosa. dan janganlah mencari-cari keburukan orang dan janganlah menggunjingkan satu sama lain. Adakah seorang diantara kamu yang suka memakan daging saudaranya yang sudah mati? Maka tentulah kamu merasa jijik kepadanya. dan bertakwalah kepada Allah. Sesungguhnya Allah Maha Penerima taubat lagi Maha Penyayang." (Q.S Al-Hujurat (49): 12).

Dari kedua ayat tersebut, dapat diketahui bahwa langkah yang diambil Nurul Hayat merupakan salah satu hal yang diperbolehkan dalam Islam.

\section{v. SIMPULAN}

LAZNAS Nurul Hayat dalam menilai keseluruhan risiko reputasi berdasarkan pada konsep reputasi yang mereka miliki dan yakini yakni, reputasi merupakan output yang terbentuk setelah adanya sistem yang baik dan kinerja yang optimal. Dari identifkasi yang dilakukan, Nurul Hayat mengelompokkan dua reputasi ini dipengaruhi oleh dua sumber, yakni internal dan eksternal. Faktor internal terdiri dari peristiwa keterlambatan mengatasi komplain, keterlambatan penjemputan donasi, tidak adanya semangat kerja, tidak dipatuhinya SOP, akuntabilitas yang kurang baik, serta tidak tepat sasaran bantaun yang dberikan. 
Berdasarkan hal tersebut, faktor risiko internal yang ada dimitigasi dengan cara membuat SOP yang baik dan merekrut orang-orang pilihan yang mau untuk dibina sebab, nilai risiko dari peristiwa tertinggi adalah pada peristiwa keterlambatan, semangat kerja, dan akuntabilitas.. Sedangkan, untuk faktor eksternal dirasa tidak akan memberikan pengaruh yag signifikan ketika lembaga sudah mampu melakukan mitgasi di risiko internal. Perbaikan selalu dilakukan secara kontinyu guna menjaga reputasi yang sudah dibangun dengan memberikan pelayanan terbaik bagi ummat. Komitmen MANDIRI menjadi nilai lebih yang dimiliki oleh Nurul Hayat dalam membentuk reputasi yang baik di mata masyarakat dan memberikan bukti nyata terkait apaapa yang sudah mereka sampaikan pada masyarakat.

\section{DAFTAR PUSTAKA}

A.B.Susanto, Himawan Wijarnako. 2004.

Power Branding : Membangun Merek Unggul dan Organisasi Pendukungnya. Quantum Bisnis\&Manajemen. Jakarta.

Airlangga, Universtity. 2009. Pedoman Penulisan Pembimbingan dan Ujian Skripsi. Surabaya : Airlangga University Press.

Al-Mubarakfuri, Shafiyyurrahman. 2010. Sirah Nabawiyah Cetakan ke-31. Jakarta Timur : Pustaka Al-Kautsar.

Ali, Muhammad Daud. 1988. Sistem Ekonomi Islam Zakat dan Wakaf. Jakarta : UI-Press
Arifin, Zainul. 2006. Dasar Dasar Manajemen Bank Syariah. Jakarta: Pustaka Alvabet.

A.Wahid.Sy. 2009. Fikih. Bandung : PT Armico.

Badan Amil Zakat Nasional. 2016. Statistik Zakat Nasional 2016. Jakarta : BAZNAS.

Baek, Irfan Syauqi; Siti Rahmawati; Ascarya. 2016. Merancang Manajemen Risiko Pengelolaan Zakat. Jakarta: Bank Indonesia.

Bashori, Muhammad Anwar. 2017. Mendorong Pengembangan Islamic SOcial Finance dalam Rangka Mewujudkan Masyarakat Sejahtera. Makassar : Bank Indonesia.

Basya, Muslim dan Irmulan Sati. 2006. Tantangan Indonesia Baru : Strategi dan Aktivitas Public Relations. Jakarta: Perhumas.

Baqi, Muhammad Fuad bin Abdul. 2007. Hadist Shahih Bukhari Muslim. Jakarta : Fathan Publishing.

Bungin, Burhan. 2008. Penelitian Kualitatif. Jakarta: Kencana.

Carter dan Damcruz. 2013. Legal Risk Management Checklist for Not-ForProfit Organization. Carters Profesional Corporation.

Clontz dan Heaven. 2015. Nonprofit Enterprise Risk Management : Best Practice and Case Studies.

Cooper, Donald R. and Emory, C. William.. 1996. Metode Penelitian Bisnis,. Jakarta : Erlangga, Edisi Kelima. 
Cheese, Peter. 2016. Mananging Risk dan Building Resilent Organizations in Riskier World. Emerald Insight, 324. Darmawi, Herman. 2005. Manajemen Risiko. Bumi Aksara, Jakarta.

Departemen Agama, RI. 2012. AlQur'anulkariim. Jakarta: Cordoba Internasional Indonesia.

Djojosoedarso, Soeisno, 2003. Prinsipprinsip Manajemen Risiko Asuransi. Jakarta : Penerbit Salemba Empat.

Dorfman. 1998. Introduction To Risk Management And Insurance. Edisi Keenam. Upper Saddle River, N.J. : Prentice Hall.

Ernawati, Hasti. 2010. Zakat Sebagai Sarana Pengentasan kemiskinan (Studi Kasus. Di Lembaga Amil Zakat"Bina Umat Mandiri" kabupaten Ngawi). Jurnal. Skripsi. Malang: UIB MALANG.

Fahmi, Irham. 2010. Manajemen Resiko. Bandung: Alfabeta.

Faisal. 2011 . Sejarah Pengelolaan Zakat di Dunia Muslim dan Indonesia (Pendekatan Teori InvestigasiSejarah Charles Peirce dan Defisit Kebenaran Liven Boeve). Lampung : Jurnal IAIN Raden Intan Lampung (Analisis, Volome IX, Nomor 2, Desember 2011)

Hakim Risal, Fathanul. 2015. Apa itu BAZ dan LAZ, Bagaimana Perilaku Pemerintah terhadap BAZ dan LAZ. Kompsiana.com. Diakses pada 03 Juli 2017 pukul 10.06 WIB.
Indonesia, Bank. 2016. Pengelolaan Zakat yang Efektif : Konsep dan Praktik di Beberapa Negara. Jakarta: Dep. Kevangan Syariah BI.

Jatmiko, Wisnu; Ari Wibisono,dkk. 2014. Sisitem Informasi Zakat. Depok: UI Press.

Karim, Adiwarman; Syaref, Azhar. 2009. Fenomena Unik di Balik Menjamurnya LAZ (Lembaga Amil Zakat) Di Indonesia. Jurnal Pemikiran dan Gagasan - Vol. I.

Katsir, A.-H. I. 2012. Perjalanan Hidup Empat Khalifah Rasul yang Agung. Jakarta: Darul Haq.

Matan, Ron; Hartnett, Bridget. 2011. How Non Profit Organizations Manage Risk.

Mubarok, Abdulloh; Fananni, Baihaqi. 2014. Penghimpunan Dana Zakat Nasional. Jurnal Permana - Vol. V.

Nina Triyani, dkk. 2015. Analisis Manajemen Risiko. Jurnal Ekonomi Islam Republika .

Okezone.com. 2015. Alasan Risma Bekukan Badan Amil Zakat. (https://news.okezone.com/read/2 015/06/26/519/1172057/alasanrisma-bekukan-badan-amil-zakat diakses pada 14 Juni 2017 pukul 13.23)

Patton, MQ. 2009. Metode Evaluasi Kualitatif. Jakarta: Pustaka Pelajar. PUSKASBAZNAS. 2016. Outlook Zakat Indonesia 2017. Jakarta: Pusat Kajian Strategis BAZNAS. 
Sholehah, et al/Jurnal Ekonomi Syariah Teori dan Terapan Vol. 6 No. 2 Februari 2019: 198-213; LEMBAGA

AMIL ZAKAT NASIONAL (LAZNAS) YAYASAN NURUL HAYAT DALAM MELAKUKAN MANAJEMEN RISIKO

REPUTASI

Pusat Baznas Online. 2017. Daftar Pemenang BAZNAS Award dan Festival Zakat.

(http://pusat.baznas.go.id/beritautama/daftar-pemenang-baznasaward-dan-festival-zakat/ diakses pada 11 Juni 2017 pukul 18.34)

Republika Online. 2015. Bekukan BAZ Surabaya, Pengamat Zakat Apresiasi Langkah Risma. (http://www.republika.co.id/berita /duniaislam/wakaf/15/06/28/nqnu50-

bekukan-baz-surabaya-

pengamat-zakat-apresiasilangkah-risma diakses pada 14 Juni 2017 pukul 08.17)

Republik Indonesia. Undang-undang Nomor 23 tahun 2011 tentang Pengelolaan Zakat. 2011. www.djpp.kemenkumham.go.id

Ridwan, Ahmad Hasan. 2011. Manajemen Zakat. Bandung : Humanity Publishing.

Qardhawi, Yusuf. 2009. Halal dan Haram. Jakarta : Robbani Press.

Salim, Abbas. 2007. Asuransi dan Manajemen Risiko. Jakarta: Raja Grafindo Persada

Soemirat, Soleh dan Elvinaro, Ardianto. 2008. Dasar-Dasar Public Relations. Bandung : PT. Remaja Rosdakarya
Sudirman. 2007. Zakat dalam Pusaran Arus Modernitas. Malang : UIN-Malang Press.

Sugiyono. 2015. Metode Penelitian Kuantitatif, Kualitatif, dan R\&D. Bandung: Alfabeta.

Tampubolon, Robert. 2004. Manajemen Resiko Pendekatan Kualitatif untuk Bank. Jakarta: Elex Media Komputindo.

Triani, Beik, dan Baga. 2015. Analisis Manajemen Risiko Pengelolaan Zakat. Jakarta : Jurnal Bank Indonesia

Wibisono, Yusuf. 2013. Mengelola Zakat Indonesia. Jakarta : Kencana.

Working Group of Zakat Core Principle. 2014. Towards an Establishment of an Efficient and Sound Zakat System.

\section{www.nurulhayat.org}

Yin, Robert K. 2013. Studi Kasus Desain \& Metode. JAkarta : PT. Raja Grafindo Persada. 